\title{
Making sense of the party wall legislation: still no easy task
}

\begin{abstract}
Notes the ambiguities within the party wall legislation. Describes the 'proceduralist' and 'rightist' approaches to interpretation of the statute. Provides examples of each approach. Traces the development of the current judicial approach to interpretation and describes surveyors' responses to this. Cites the recent case of Frances Holland School $v$ Wassef [2001] as demonstrating the consistency of the judicial approach. Discusses issues, raised by the case, relating to ex parte awards and the statutory definition of 'owner'. Concludes that surveyors should follow a rightist approach to the legislation whilst also understanding the limits of the rightist doctrine.
\end{abstract}

\section{Keywords}

party wall, surveyor, award, jurisdiction, owner, ex parte, statutory interpretation

\section{Introduction}

Ambiguities within the Party Wall etc. Act 1996 make the statute notoriously difficult to interpret. ${ }^{1}$ Indeed, these ambiguities predate the introduction of the current $\mathrm{Act}^{2}$ and explain the tradition of debate which has existed amongst practitioners under the earlier London Building Acts, and which continues under the present legislation. ${ }^{3}$

Many of these debates address the nature of the surveyor's statutory role and focus on the risks for surveyors of inadvertently creating invalid awards. Particular areas of disagreement are often rooted in more fundamental differences of opinion about the 
underlying legislative purpose of the statute. In this context two broad schools of interpretation can be identified. The first has been described as the 'proceduralist' school, and the second, as the 'rightist' school. ${ }^{4}$

This paper describes these two schools of interpretation and provides examples of their approach to the legislation. Based on recent reported caselaw, it also considers which approach should properly be followed by surveyors appointed under the present Act.

\section{Two schools of interpretation}

\section{Proceduralist school}

The 'proceduralist' school places its emphasis on the various procedural mechanisms within the legislation. These include the service of notices and the appointment of surveyors to resolve disputes. These mechanisms are viewed as providing a procedural framework for resolving a variety of disputes between neighbouring owners during construction operations affecting a common boundary.

In undertaking what is effectively a form of alternative dispute resolution (ADR), the surveyors are often described as delivering 'helpful and cheap' solutions to problems ${ }^{5}$ which would otherwise have to be referred to solicitors, and ultimately, to the courts. ${ }^{6}$

This approach emphasises the practical, pragmatic and common-sense approach which surveyors bring to the resolution of construction-related disputes and it would certainly challenge the notion that the surveyors perform any kind of arbitral or 'paralegal' function. ${ }^{7}$ 


\section{Rightist school}

The 'rightist' school would not fundamentally disagree with this analysis but would argue that it neglects the main purpose of the legislation. Specifically, it sees this as being concerned with the regulation of property rights between the parties. ${ }^{8}$

In particular, by granting the right to undertake work to boundary structures, the Act is seen as authorising an interference in the property rights of adjoining owners. As adjoining owners are thereby deprived of any protection by the law of trespass, the Act is seen as providing an alternative form of protection. This takes the form of a statutory right not to be subjected to unnecessary inconvenience during the course of the works as well as (usually) a right to have any damage to their property made good on completion. ${ }^{9}$

The rightist school would argue that the surveyors' statutory function should be viewed in these terms. It would reject the notion that the surveyors provide a general alternative dispute resolution service for the parties. Instead, it would argue that, jointly, they constitute a statutory tribunal ${ }^{10}$, which is charged with the specific task of achieving an equitable balance between the competing statutory rights of each of the parties.

Most advocates of the rightist school would not suggest that this role was directly akin to that of an arbitral tribunal. ${ }^{11}$ Most would share the proceduralist school's understanding of the practical and technical nature of the surveyors' task. This 
involves surveyors in achieving a balance between the competing rights by addressing operational issues rather then adjudicating directly on the rights themselves.

Nevertheless, certain legal consequences inevitably arise from the classification of the surveyors as a tribunal. In particular, in common with all tribunals, the surveyors' tribunal must act only within its proper jurisdiction and must only exercise powers which have been properly conferred upon it. ${ }^{12}$

\section{The different approaches}

It can be seen from this analysis that the rightist school must inevitably favour a more restrictive interpretation of the legislation. This applies, both to the overall scope of the legislation, and to the nature of surveyor's role within it.

In contrast, by emphasising the general benefits of the statutory procedures, and of the surveyors' involvement within them, the proceduralist school takes a more liberal approach to interpretation. For this reason it will often be far more willing to contemplate the use of the legislation to resolve issues in novel situations and to sanction the exercise of powers by surveyors which facilitate this.

\section{Examples of the different approaches}

\section{Approach to the scope of the legislation}

Section 1(5) of the Act provides a useful example of the two approaches in the context of the general scope of the legislation. That section regulates the construction of new boundary walls where land is presently unbuilt upon. 
The proceduralist school argues that a building owner can elect to serve notice when constructing a new wall along his own side of a boundary, even where this would involve no encroachment onto neighbouring land. ${ }^{13}$ By triggering the statutory procedures, service of a notice is seen as inherently beneficial. It provides for the involvement of surveyors in a potentially problematic situation whilst also providing the building owner with a statutory right of access onto adjoining land.

The rightist school rejects this interpretation. It argues that the statutory procedures only have relevance where there is some interference with the property rights of the adjoining owner. In the context of section 1(5) this would restrict the building owner's entitlement to serve notice to those situations where he intends to exercise the statutory right, under section 1(6), to place projecting foundations on his neighbour's side of the boundary line. ${ }^{14}$

\section{Approach to the surveyors' statutory role}

The proceduralist school's approach to the surveyors' statutory role is best illustrated by the practice which developed, over many years, under the London Building Acts. Once appointed under that legislation, surveyors would adopt a constructive and pragmatic approach to their task. They would frequently address a range of boundaryrelated issues as they arose during a construction project, whether or not they strictly fell within the legislation. A high level of co-operation between surveyors also ensured that matters could be progressed efficiently without necessarily following the stated legislative requirements to the letter. 
Indeed, with some justification, this approach is often seen as one of the strengths of the London regime. In this context, Leach has noted that that Act's provisions worked well, precisely because "their operation has been left so much to surveyors who have not been too analytical or too inquisitive as to the exact scope of their powers thereunder". ${ }^{15}$

Clearly, a positive and co-operative culture developed amongst surveyors practising under the London Building Acts. This ensured that, for years, the proceduralist school, with its ADR model of the surveyors' role, delivered very significant benefits to the clients who were served by it.

For as long as this practice remained the norm there is also evidence that, on occasions, the courts were prepared to take their lead from surveyors and to endorse the custom and practice which had developed, or at least, to turn a blind eye to it. ${ }^{16}$

\section{The judicial approach}

\section{Development of current position}

The difficulty for the proceduralist school lies in the fact that, subject to this small number of possible exceptions, the overwhelming body of reported case law favours the approach taken by the rightist school.

Because of the successful operation of London custom and practice, comparatively few cases have come before the courts since the enactment of modern party wall legislation in 1855. The case law has therefore taken time to develop. However, by the 1970's the judicial approach to the legislation had become clear and this was 
reiterated with devastating clarity in the seminal case of Gyle-Thompson $v$ Wall Street (Properties) $L t d .{ }^{17}$ Brightman J's words are as clear an endorsement of the rightist school's approach as one is likely to find anywhere:

"...the....Act give[s] a building owner a statutory right to interfere with the proprietary rights of the adjoining owner without his consent and despite his protests. The position of the adjoining owner, whose proprietary rights are being compulsorily affected, is intended to be safeguarded by the surveyors.....

Those surveyors are in a quasi-judicial position with statutory powers and responsibilities......therefore.....the steps laid down by the Act should be scrupulously followed throughout, and short cuts are not desirable........the approach of surveyors to those requirements ought not to be casual." ${ }^{18}$

In this case the court held that the surveyors had exceeded their statutory powers by awarding that a party fence wall could be reduced in height without the consent of one of its owners. No such right existed in the 1939 legislation under which the case was decided. It also held that, in any event, the surveyors had no jurisdiction to act because of their failure to comply with the Act's strict requirements regarding service of notices and appointment of surveyors.

Lest surveyors were in any doubt that the courts would no longer tolerate the established custom and practice, the case of Woodhouse v Consolidated Property Corporation $\mathrm{Ltd}^{19}$ provided a further warning. In that case a Third Surveyor's award 
which purported to deal with damage that arose before surveyors had actually been appointed was set aside.

\section{Response by surveyors}

Anstey and Vegoda's observations on this case provide some indication of how it was received by the profession:

".....the Court of Appeal.....made the astonishing ruling that surveyors only had power to decide whether and how a building owner had the right to carry out works under [the Act]. In order to justify this judgement, they indulged in some very selective quotation from the 1939 Act....This was, however, plainly wrong - and there is no doubt about it.

.......Unfortunately, it was clear that the surveyors had been appointed after the damage had been done, and although it was the custom of surveyors not to let petty procedural matters like that stand in the way of helpful and cheap resolution of differences, this case tended to make them more wary about doing so." ${ }^{20}$

Although many surveyors undoubtedly became more wary, there remains, as indicated by the tone of the quotation, a deep-seated reluctance to accept the legitimacy of the court's apparently new approach to the legislation. The established custom and practice had operated successfully in the capital for over a century and had, at the very least, received the courts' tacit approval during this time. Many surveyors understandably felt that it was now rather late in the day for the courts to 
challenge this custom and practice and regarded these decisions as an unwarranted interference in areas properly falling within their own areas of competence.

Unfortunately, although taking time to develop in coherent form, the courts' approach is well supported by a significant number of earlier decisions ${ }^{21}$ and does now represent the consistent and established view of the judiciary towards the legislation. Although personally unhappy about the changes, Anstey had no illusions about their effect and provided numerous warnings about their implications for practitioners. ${ }^{22}$ Despite these warnings, many surveyors remain sceptical about the message and this partly explains the continuing popularity of the proceduralist school. However, unless these warnings are heeded, surveyors' awards will continue to be overturned by the courts.

\section{Frances Holland School $v$ Wassef}

A recent case provides the latest example of this. The decision in Frances Holland School $v$ Wassef ${ }^{23}$ once again reaffirms the rightist approach which is now being followed by the judiciary. This case set aside a surveyor's award on the basis that it was made without proper jurisdiction under the 1939 Act.

The case arose in connection with construction works undertaken by the Frances Holland School in London SW1. The works involved the demolition and rebuilding of two buildings on the School's land. Both buildings shared party walls with a neighbouring property. That property was occupied by $\mathrm{Mr}$ and Mrs Wassef as statutory tenants under the Rent Act 1977. The work also involved adjacent excavations, which necessitated underpinning the Wassef's property. 
Notices were served on the Wassefs under the 1939 Act and surveyors were appointed by each of the parties. The surveyors then published a number of awards which regulated the various stages of the demolition and rebuilding work.

However, there came a point when the Wassef's surveyor wished to publish a further award dealing with certain outstanding matters. The School's surveyor felt that these were best left until the works had been completed and this resulted in an empasse. In an attempt to resolve this, the Wassef's surveyor thereupon published an ex parte award which addressed the outstanding issues.

The School appealed against this award to the county court. During the course of the proceedings, the court had to consider whether the surveyor had proper jurisdiction to make the award. This was potentially compromised by two issues.

\section{Definition of "owner"}

The first issue related to whether the Wassefs, as statutory tenants, fell within the definition of "owner" in the Act. If they did not then the service of notices, and all subsequent statutory proceedings, would be rendered invalid.

The judge expressly approved the rightist doctrine that the party wall legislation was concerned with the regulation of property rights between owners. On this basis, the legislation must be limited to those who hold legal interests in land and statutory tenants must, by definition, be excluded from this. 
The surveyors therefore had no jurisdiction to make awards in the present case, as the Wassefs should never have been served with notices at the outset.

\section{Jurisdiction to make 'ex parte' awards}

The second issue concerned the circumstances in which a party-appointed surveyor becomes entitled to make an award ex parte. The legislation authorises this in circumstances where the other surveyor refuses to act or fails to do so for 10 days after having been requested to do so in writing. ${ }^{24}$

In the present case the Wassef's surveyor had served the appropriate request but the other surveyor had promptly responded to the effect that he did not consider any further action was appropriate until completion of the works. 10 days later the Wassefs' surveyor then issued the ex parte award, citing this response as a refusal to act.

Once again, the court favoured a rightist approach, which had close parallels with the decision in Gyle-Thompson. Because of the Act's drastic consequences (interference with property rights) the court noted that surveyors are required to comply strictly with its provisions.

The Wassef's surveyor had failed to do this. He relied on procedural steps designed to establish a neglect to act as justification for asserting that the other surveyor had refused to act. According to the evidence the court was not satisfied that there had been either a refusal or neglect to act within the terms of the legislation. 
The judgement provides useful guidance for surveyors when exercising the Act's powers to make ex parte awards:

".....the surveyor can rely either upon a refusal, or upon a [written request] that complies with the provisions of the Act, or, where appropriate, upon both grounds. The relevant grounds must be expressed in the ex parte award.

In this case, there was no reference to a neglect to Act by [the School's surveyor]. Accordingly, the ex parte award is inconsistent with the reference to the 10-day time limit in the [written request]........In those circumstances I consider that the ex parte award is bad on its face and invalid."25

\section{Conclusions}

This latest case should come as no surprise. It simply reiterates a judicial approach to the interpretation of the party wall legislation which is now firmly established.

It confirms, once again, that the courts will instinctively apply the rightist school of interpretation to cases under the Act. They see the legislation as regulating substantive property rights between neighbouring owners. Because the Act authorises an interference with those rights, the courts will insist that its procedures are followed to the letter. They will also insist that surveyors only address issues which fall properly within the ambit of the legislation.

Although the proceduralist approach undoubtedly worked well under the London Building Acts for many years, the courts have, for some time, taken an entirely 
different approach to the legislation. A failure by surveyors to appreciate this will result in them acting outside their jurisdiction or in excess of their statutory powers. In either event, this may lead to the courts declaring their awards to be invalid.

Despite this situation, it must also be said that the rightist approach only operates to define the parameters of the legislation. It certainly represents no change to the substance of the surveyor's role, which continues to involve the practical and common sense approach which has always been emphasised by the proceduralist school. The reported cases clearly establish that, where the surveyors remain within the parameters of the legislation, the courts will rarely interfere with the contents of their awards. $^{26}$

This situation presents a significant challenge for surveyors. They must continue to perform their traditional function but within the tight legal constraints which now prescribe the limits of their role. This requires the simultaneous and instinctive exercise of a number of surveying and legal skills. It is certainly no easy task for anyone - whichever school they belong to in the debate.

\section{Notes and references}

\footnotetext{
1 Discussed in Ainsworth, R. (2000) 'The Party Wall etc. Act 1996: Differences of opinion in interpreting section 1' in Structural Survey, Vol. 18, No. 5, pp. 213 - 217

${ }^{2}$ It was also referred to in the context of the Metropolitan Building Act 1855 by Montagu Smith J. in Hunt $v$ Harris [1865] 19 CB (NS) 13, at p. 41 and by Chitty, J. in Fillingham $v$ Wood [1891] 1 Ch 51, at pp. 54 \& 56. In the context of the London Building Acts (Amendment) Act 1939 it has been referred to in Leach, W. A. (1961) Party Structure Rights in London, Estates Gazette, p. 9

${ }^{3}$ Most notably within the membership of the Pyramus \& Thisbe Club and through the electronic Party Wall and Rights to Light Discussion Forum at www.jiscmail.ac.uk/lists/partywalls.html

${ }^{4}$ Chynoweth, P. (1999) 'Work in Pursuance', 17 December, Party Wall and Rights to Light Discussion Forum Archives, www.jiscmail.ac.uk/lists/partywalls.html, accessed 27 October 2001
} 
${ }^{5}$ Anstey, J. \& Vegoda, V. (1997) An Introduction to the Party Wall etc. Act 1996, Lark Productions, p. 135

${ }^{6}$ See, for example, the comments by Lord Lytton during the Second Reading of the Party Wall Bill in the House of Lords, Wednesday 31 January 1996, Parliamentary Debates (Hansard): House of Lords Official Report, Vol. 568, No. 35, col. 1536

${ }^{7}$ Hampton, P. (1999) Party Structures: The Party Wall etc. Act 1996, Architecture and Surveying Institute, pp. $2.1-2.2$

${ }^{8}$ See, for example, Hart, M.., Talk to the Pyramus \& Thisbe Club, London, 24 September 1982, reported in The Collected Papers of the Pyramus \& Thisbe Club, Vol. 1, 1974 - 1989, p.93

${ }^{9}$ Discussed in Chynoweth, P. (2000a) 'Unnecessary Inconvenience and compensation within the party wall legislation', in Structural Survey, Vol. 18, No.2, pp. 99 - 104

${ }^{10}$ Discussed in Chynoweth, P. (2001) 'Impartiality and the Party Wall Surveyor', in Construction Law Journal, Vol. 17, No.2, pp. 127 - 137

11 The opposing argument is presented by Bowden, D. (2000) 'The appointed surveyor as arbitrator', in Structural Survey, Vol. 18, No. 5, pp. 199 -204

12 Chynoweth, P. (2000b) 'Invalid awards and how to avoid them' in Structural Survey, Vol. 18, No. 4, pp. $168-176$

13 Redler, A. (1999) 'Section 1 - Application of', 15 December, Party Wall and Rights to Light Discussion Forum Archives, www.jiscmail.ac.uk/lists/partywalls.html, accessed 27 October 2001

${ }^{14}$ Bickford-Smith, S. \& Sydenham, C. (1997) Party Walls: The New Law, Jordans, p. 15

${ }^{15}$ Leach, W. A. (1961) Party Structure Rights in London, Estates Gazette, p. 9

${ }^{16}$ See, for example, Whitefleet Properties Ltd v St Pancras Building Society [1956] 167 EG 262

${ }^{17}$ Gyle-Thompson v Wall Street (Properties) Ltd [1974] 1 All ER 295

18 ibid., p. 304

${ }^{19}$ Woodhouse v Consolidated Property Corporation Ltd [1993] 1 EGLR 174

${ }^{20}$ Anstey, J. and Vegoda, V. (1997) op cit.

${ }^{21}$ See, for example, the decisions in Sims v The Estates Company [1866] 14 LT 55; Crofts v Haldane [1867] LR 2 QB 194; Hobbs, Hart \& Co. v Grover [1899] 1 Ch 11; Leadbetter v Marylebone Corporation [1904] 2 KB 893; Burlington Property Company Ltd v Odeon Cinemas Ltd [1939] 1 KB 633. More generally, see also the discussions about the nature of the statutory regime in Standard Bank of British America v Stokes [1878] 9 Ch 68 and Adams v Marylebone Borough Council [1907] 2 KB 822

${ }^{22}$ Including, Anstey, J. (1996) 'The broad sweep will leave you covered in soot' in Structural Survey, Vol. 14, No. 1, pp. 49 - 50

${ }^{23}$ Frances Holland School v Wassef [2001] 29 EG 123

${ }^{24}$ London Building Acts (Amendment) Act 1939, s. 55(e). With some minor changes, the same provision now appears in substantially the same form as Party Wall etc. Act 1996, ss. 10(6) and 10(7).

${ }^{25}$ Frances Holland School $v$ Wassef, op cit. 
Paul Chynoweth

${ }^{26}$ Chynoweth, P. (2000b), op cit., p. 173 